\title{
Activation of Phosphatidylinositol-3 Kinase (PI-3K) and Extracellular Regulated Kinases (Erk1/2) Is Involved in Muscarinic Receptor- Mediated DNA Synthesis in Neural Progenitor Cells
}

\author{
Bing-Sheng Li, ${ }^{1}$ Wu Ma, ${ }^{4}$ Lei Zhang, ${ }^{3}$ Jeffery L. Barker, ${ }^{2}$ David A. Stenger, ${ }^{4}$ and Harish C. Pant ${ }^{1}$ \\ ${ }^{1}$ Laboratory of Neurochemistry and 'Laboratory of Neurophysiology, National Institute of Neurological Diseases and \\ Stroke, and ${ }^{3}$ Behavioral and Endocrinology Branch, National Institute of Mental Health, National Institutes of Health, \\ Bethesda, Maryland 20892, and ${ }^{4}$ Center for Bio/Molecular Science and Engineering, Naval Research Laboratory, \\ Washington, DC 20375
}

\begin{abstract}
Muscarinic acetylcholine receptor (mAChR), a member of the G-protein-coupled receptors (GPCRs) gene superfamily, has been shown to mediate the effects of acetylcholine on differentiation and proliferation in the CNS. However, the mechanism or mechanisms whereby $\mathrm{mAChRs}$ regulate cell proliferation remain poorly understood. Here we show that in vitro bFGFexpanded neural progenitor cells dissociated from rat cortical neuroepithelium express muscarinic acetylcholine receptor subtype mRNAs. We demonstrate that stimulation of these mAChRs with carbachol, a muscarinic agonist, activated extracellular-
\end{abstract}

regulated kinases (Erk1/2) and phosphatidylinositol-3 kinase (PI-3K). This, in turn, stimulated DNA synthesis in neural progenitor cells. MEK inhibitor PD98059 and PI-3K inhibitors wortmannin and LY294002 inhibited a carbachol-induced increase in DNA synthesis. These findings indicate that the activation of both PI-3 kinase and MEK signaling pathways via muscarinic receptors is involved in stimulating DNA synthesis in the neural progenitor cells during early neurogenesis.

Key words: progenitor cell; proliferation; muscarinic receptors; phosphorylation; protein kinase-B; MAP kinase
It is well established that, during development, neurotransmitters act as growth regulatory signals to control cell proliferation, differentiation, and gene expression by activating receptors coupled to specific second messenger pathways (Lauder, 1993; Liu et al., 1997). Now there has been strong support for the presence of muscarinic receptors in astrocytes in mammalian CNS (Stephan and Sastry, 1992; Hosli and Hosli, 1993). In these cells the muscarinic receptor agonists caused hydrolysis of phosphoinositides, mobilization of intracellular $\mathrm{Ca}^{2+}$, and activation of phospholipases $\left(\mathrm{A}_{2}\right.$ and $\left.\mathrm{D}\right)$, resulting in the inhibition of adenylate cyclase activity and the induction of the immediate early genes c-fos and c-jun (Trejo and Brown, 1991). Ashkenazi et al. (1989) found that activation of the muscarinic receptors $\mathrm{m} 1, \mathrm{~m} 3$, and $\mathrm{m} 5$ is involved in proliferation in rat cortical astrocytes. An increase of proliferation in these cells also was observed in the presence of carbachol (Guizzetti et al., 1996). The mitogenic effects of the muscarinic receptor agonist carbachol also have been studied in oligodendrocyte progenitors. Carbachol stimulated DNA synthesis, and this stimulation was prevented by atropine (Cohen et al., 1996). In addition, mAChRs also have been implicated in learning and memory in human and other mammals (Blokland, 1995) via the activation of extracellular-regulated kinases (Erk1/2; Rosenblum et al., 2000). Erk1/2 activation has been correlated

\footnotetext{
Received June 8, 2000; revised Nov. 29, 2000; accepted Dec. 5, 2000.

We thank Drs. Philip Grant and J. Silvio Gutkind for their excellent suggestions and for critically reading this manuscript. We also thank Devee Schoenberg for editing this manuscript. We thank Dr. Qian $\mathrm{Hu}$ for his help in calcium imaging. Finally, we thank Dr. Carolyn Smith in the National Institute of Neurological Diseases and Stroke Light Microscopy Facility for her assistance in confocal microscopy.

Correspondence should be addressed to Dr Harish C. Pant, Laboratory of Neurochemistry, National Institute of Neurological Diseases and Stroke, National Institutes of Health, Building 36, Room 4D20, 9000 Rockville Pike, Bethesda, MD 20892-4130. E-mail: hcp@codon.nih.gov.

Copyright (C) 2001 Society for Neuroscience 0270-6474/01/211569-11\$15.00/0
}

with synaptic plasticity (Orban et al., 1999), including long-term potentiation (LTP). mAChRs have been shown to modulate LTP in the cortex and hippocampus (Jerusalinsky et al., 1997). In a recent study atropine was found to attenuate cortical LTP in vivo (Jones et al., 1999).

The above studies clearly demonstrate that acetylcholine and its agonist carbachol stimulate muscarinic receptors and promote DNA synthesis and the proliferation of primary astrocytes from prenatal rat brain. Also, in transfected Chinese hamster ovary (CHO) cells expressing recombinant muscarinic receptors (Ashkenazi et al., 1989) and oligodendrocyte progenitors (Cohen et al., 1996), similar effects of the activation of muscarinic receptors have been demonstrated. Little, however, is known about the signal transduction mechanisms involving $\mathrm{mAChR}$ activation in regulating the proliferation of neural progenitors during early mammalian brain development. Hence, it is important to understand the role of mAChRs in regulating DNA synthesis and cell proliferation in neural progenitor cells during early neurogenesis.

The muscarinic cholinergic receptor ( $\mathrm{mAChR}$ ) belongs to the superfamily of G-protein-coupled receptor (GPCR) genes and mediates the effects of acetylcholine in the CNS (Hepler and Gilman, 1992; Hadcock and Malbon, 1993; Fraser et al., 1994; Gudermann et al., 1997). Recently, it has been shown that mAChR mediates $\mathrm{G}_{\beta \gamma}$-dependent activation of MAP kinase, phosphatidylinositol-3 kinase (PI-3K; Crespo et al., 1994; Wan et al., 1996; Lopez-Ilasaca et al., 1997), and PI-3 kinase-induced activation of Akt (Murga et al., 1998). Akt was implicated in the pathway regulating cell survival in response to growth factors in a variety of cellular systems (Datta et al., 1997; Brunet et al., 1999). Activation of MAP kinases appears to be a critical component of growth-promoting pathways (Davis, 1993). In addition to MAP kinases, PI-3Ks are thought to control DNA synthesis in CHO cells (McIlroy et al., 1997), 3 T3 cells (Roche et al., 1994), 
A
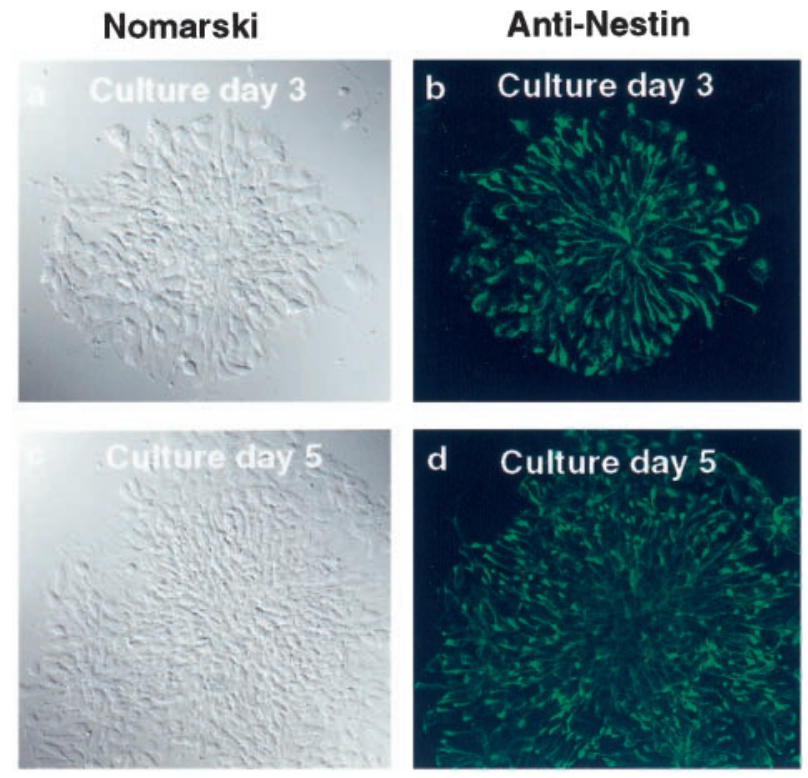

B

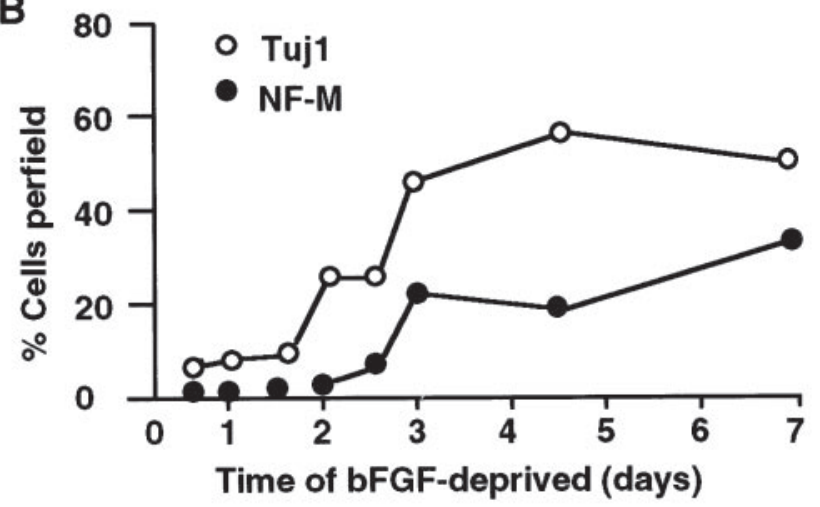

C
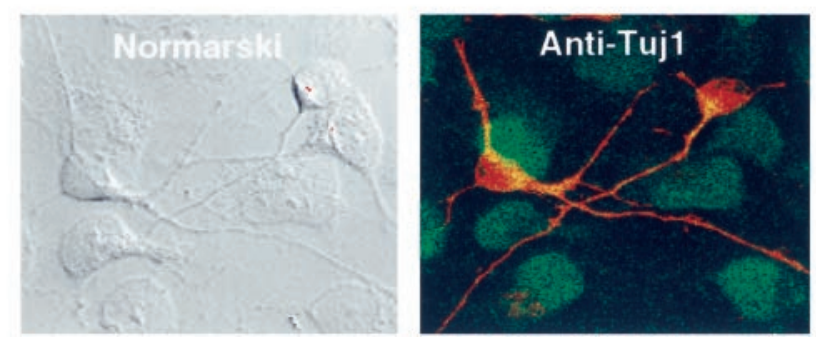

Figure 1. bFGF expansion and differentiation of cortical neuroepithelial cells. $A$, Rat cortical progenitor cells were maintained in serum-free medium containing bFGF for days 1,3 , and 5 . The cells on days 3 and 5 were fixed and stained for immunofluorescence with anti-nestin monoclonal antibody. Note the radial morphology of the cells, showing an increase in cell numbers. $B$, Differentiation was initiated by removing bFGF. Rapidly dividing nestin-positive progenitor cells after $5 \mathrm{~d}$ in bFGF $(10 \mathrm{ng} / \mathrm{ml})$ were labeled with $10 \mu \mathrm{M}$ BrdU during the last $24 \mathrm{hr}$ of proliferation. Then differentiation was initiated by the withdrawal of bFGF (day 0) and continued for up to $7 \mathrm{~d}$. At indicated times the cells were fixed and stained for BrdU and the neuronal antigens NF-M and TuJ1 or the glial antigen GFAP (data not shown). Ratio of cells doublestained for BrdU and each neuronal antigen to total $\mathrm{BrdU}^{+}$cells per $20 \times$ field are shown. (○), $\mathrm{TuJ}_{1}^{+} ;(\bullet),{\mathrm{NF}-\mathrm{M}^{+}}^{+}$C, Typical clones were immunostained with BrdU and neuron-specific antigen TuJ1 antibody after removal of the bFGF for $7 \mathrm{~d}$. melanoma cells, T cells (Ahmed et al., 1997; Brennan et al., 1997), and granule neuron progenitor cells (Cui et al., 1998). However, the mechanism or mechanisms whereby PI-3 kinase and MAP kinase signaling from muscarinic receptors regulate neural progenitor cell proliferation remain primarily unknown.

In this study we have identified that the basic fibroblast growth factor (bFGF)-expanded neural progenitor cells dissociated from rat cortical neuroepithelium express $\mathrm{m} 2, \mathrm{~m} 3$, and $\mathrm{m} 4$ subtype mRNAs. We show that the acetylcholine agonist carbachol, acting via muscarinic receptors, activated PI-3 kinase and extracellularregulated kinases (Erk1/2). This, in turn, resulted in stimulating DNA synthesis in neural progenitor cells. These findings demonstrate that the PI-3 kinase and MAP kinase signaling pathways via $\mathrm{mAChRs}$ are involved in neural progenitor cell proliferation during early neurogenesis.

\section{MATERIALS AND METHODS}

Cell culture. Neural progenitor cells were cultured as previously described (Ma et al., 1998). Briefly, pups were removed from pregnant Sprague Dawley rats (Taconic Farms, Germantown, NY). The formative dorsal telencephalic neuroepithelium was dissected from rats of embryonic days 13-13.5 (E13-E13.5). Tissue was dissociated by brief mechanical triturating in HBSS. The dissociated cells were collected by centrifugation and resuspended in a serum-free Neurobasal (NB) medium supplemented with B27, $0.5 \mathrm{~mm}$ L-glutamine, and $10 \mathrm{ng} / \mathrm{ml}$ recombinant human bFGF (Intergen, Purchase, NY). Cells $\left(25 \times 10^{3}\right)$ were plated in $35 \mathrm{~mm}$ plastic dishes precoated with $10 \mu \mathrm{M}$ poly-L-lysine and $1 \mu \mathrm{g} / \mathrm{ml}$ bovine plasma fibronectin (Life Technologies, Gaithersburg, MD).

Reverse transcriptase-PCR (RT-PCR) analysis. Cortical progenitor cells expanded by bFGF for 1-5 d were harvested before differentiation. For RT-PCR analysis of muscarinic receptor subtype mRNA expression in cultured cortical progenitor cells, total RNA was isolated by a single-step guanidinium-thiocyanate/phenol-chloroform extraction protocol and then reverse-transcribed and amplified. Total RNA amounts in samples were normalized by the amplification of a $441 \mathrm{bp}$ fragment of glyceraldehyde-3-phosphate dehydrogenase mRNA. The primers were as follows: m1, 5'-AGCTCAGAGAGGTCACAG-3' and 5'-TCGGTCTCGGCCTTTCTTGGT-3'; m2, 5'-CACGAAACCTCTGACCTACCC-3' and 5'-TCTGACCCGACGACCCAACTA-3'; m3, 5'-GTGACAACTGTCAGAAGG-3' and 5'-CCAGGACCATGATGTTGT-3'; m4, 5'GAATTCGTTCACAAGCATCGACCTG-3' and 5'-CTCGAGTGGTGGCCTCTGCGGTGGAC-3'; m5, 5' -CCCGTAGAAGCACCTCAACAACAGG-3' and 5'-TTTGATGACTGAGGTTGGGATCCGG-3'; GAPDH, 5'-GGACATTGTTGCCATCAACGAC-3' and 5'-ATGAGCCCTTCCACGATGCCAAAG-3'. Amplification was performed for 40 cycles at $95^{\circ} \mathrm{C}$ for $45 \mathrm{sec}$, at $54^{\circ} \mathrm{C}$ for $30 \mathrm{sec}$, and at $72^{\circ} \mathrm{C}$ for $60 \mathrm{sec}$.

$\left[{ }^{3} \mathrm{H}\right]$ thymidine and BrdU incorporation assay. Neural progenitor cells were grown to an approximate density of $1 \times 10^{5} \mathrm{cells} / \mathrm{cm}^{2}$ in $35 \mathrm{~mm}$ plastic dishes for $3 \mathrm{~d}$. Before agonist stimulation the cultures were deprived of bFGF for $24 \mathrm{hr}$ to decrease the basal levels of proliferation. After the agonist was added for $24 \mathrm{hr}, 2 \mu \mathrm{Ci} / \mathrm{ml}$ [methyl- ${ }^{3} \mathrm{H}$ ] thymidine was incubated for the last $6 \mathrm{hr}$ of the incubation at $37^{\circ} \mathrm{C}$ under an atmosphere of $5 \% \mathrm{CO}_{2} / 95 \%$ air. Cells were washed three times with ice-cold PBS, and 5\% trichloroacetic acid (TCA) was added for $20 \mathrm{~min}$ at $4^{\circ} \mathrm{C}$. The monolayer was washed once with $5 \%$ TCA, and a mixture of $0.1 \mathrm{~N} \mathrm{NaOH}$ and $1 \%$ SDS was added for 10 min. Samples were transferred to a scintillation vial, and the radioactivity was counted on a Beckman LS3801 scintillation counter. For the BrdU incorporation assay, $4 \mathrm{hr}$ before fixation with $70 \%$ ethanol the BrdU $(10 \mu \mathrm{M})$ was added to the cultures. Cells incorporating BrdU were identified by using the FITC-conjugated monoclonal anti-BrdU (Becton Dickinson, Mountain View, CA).

BrdU labeling of rat embryos. BrdU labeling of cells in the S-phase of the cell cycle was performed according to the protocol described by Hayashi et al. (1988). In brief, BrdU (100 mg/gm of body weight) was injected intraperitoneally into rat pregnant females at E16.5 of gestation. These rats were killed $8 \mathrm{hr}$ after injection, and the uteri were removed; complete deciduas or embryos were fixed in $4 \%$ paraformaldehyde at $4^{\circ} \mathrm{C}$ overnight and processed for immunohistochemistry. The sections were incubated with an anti-BrdU monoclonal antibody (Boehringer Mannheim, Indianapolis, IN) at a 1:10 dilution. Staining was performed according to the protocol described as above. $\mathrm{BrdU}^{+}$cells were counted 
A

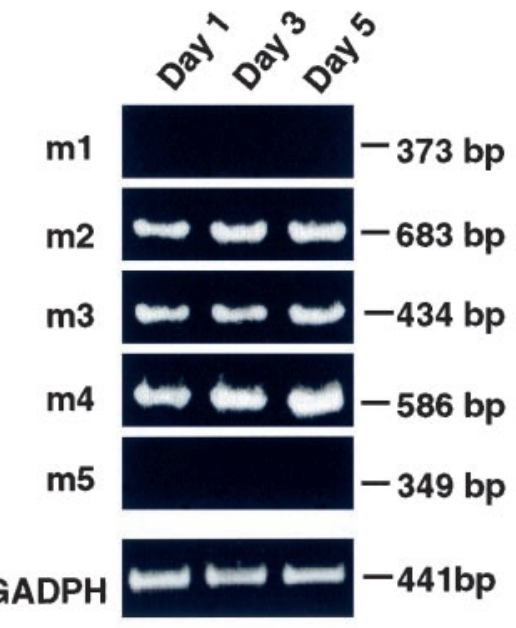

B
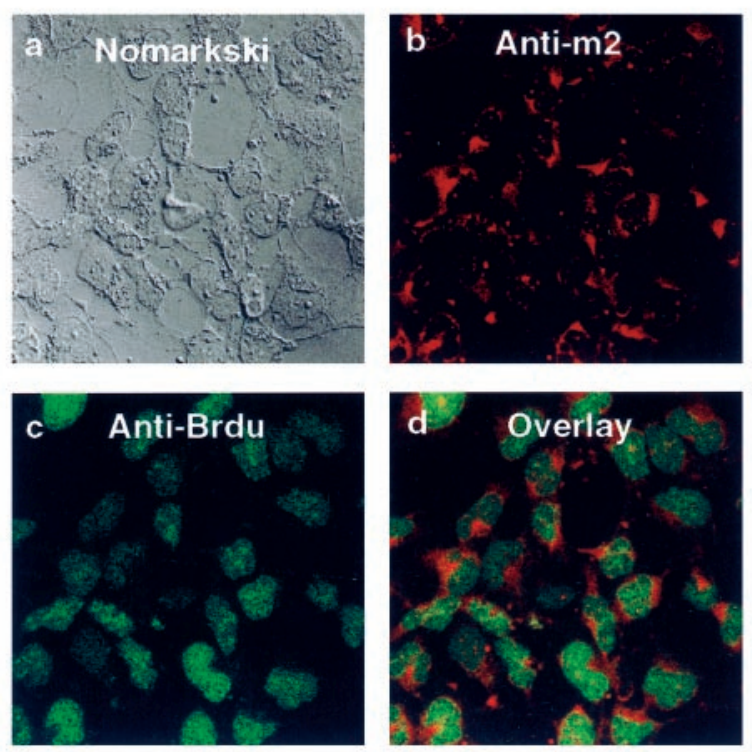

C

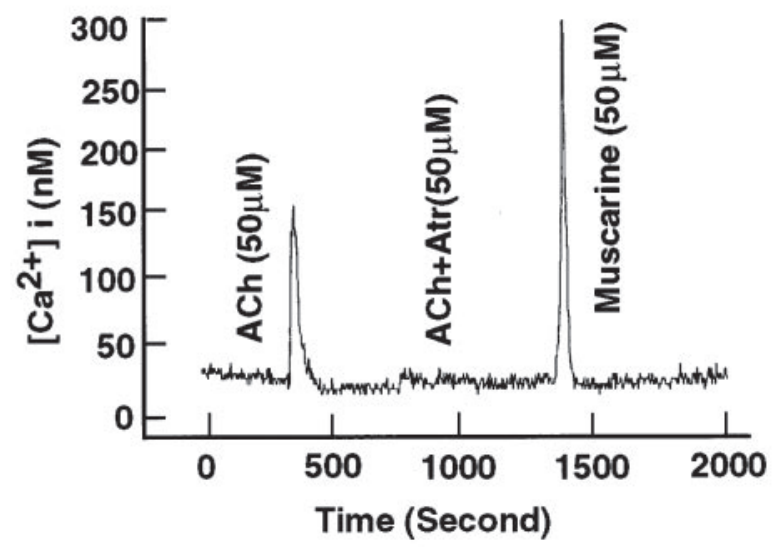

Figure 2. Rat cortical progenitor cells express muscarinic receptor $\mathrm{m} 2$, $\mathrm{m} 3$, and $\mathrm{m} 4$ subtypes. $A$, RT-PCR analysis of $\mathrm{mAChR}$ gene expression in rapidly dividing cortical precursor cells. Total RNA isolated from bFGFexpanded for day 1 (lane 1), day 3 (lane 2), and day 5 (lane 3 ) was reverse-transcribed and analyzed by PCR as described in Materials and Methods. As indicated at left, oligonucleotides corresponding to the following gene products were used: $\mathrm{m} 1, \mathrm{~m} 2, \mathrm{~m} 3, \mathrm{~m} 4, \mathrm{~m} 5$, and GADPH. The molecular mass of the PCR products is indicated on the right. B, Cortical progenitor cells were bFGF-expanded for $4 \mathrm{~d}$ and then labeled with $10 \mu \mathrm{M}$ BrdU for an additional $24 \mathrm{hr}$. Cells were fixed and immuno- in the 10 different regions of the ventricular and subventricular zones of cerebral cortex. Values are expressed in a percentage of control as the means \pm SEM of three independent experiments.

Apoptosis assay. Cortical progenitor cells were grown in $35 \mathrm{~mm}$ dishes for $3 \mathrm{~d}$ in the presence of $\mathrm{bFGF}$, and then bFGF was deprived for $24 \mathrm{hr}$. They were treated as indicated for DNA synthesis. In control and CCh-treated cells and cells treated with inhibitor cultures, fragmented DNA was visualized by the terminal deoxynucleotidyltransferasemediated dUTP nick end labeling (TUNEL) procedure with an in situ cell death detection kit (AP) from Boehringer Mannheim, following the manufacturer's instructions. Labeled nuclei and the total number of cells were counted in 10 independent fields.

Immunoprecipitation and in vitro kinase assay. For kinase activity assays the progenitor cells were grown in $35 \mathrm{~mm}$ dishes for $3 \mathrm{~d}$, deprived of bFGF for $24 \mathrm{hr}$, and treated as described in the figure legends. After treatment the cells were scraped into $1 \mathrm{ml}$ of lysis buffer $(10 \mathrm{~mm}$ Tris- $\mathrm{HCl}$, pH $7.5,1 \%$ sodium deoxycholate, $1 \%$ Nonidet P-40, $150 \mathrm{~mm}$ $\mathrm{NaCl}$, and protease and phosphatase inhibitors). Extracts were sonicated and centrifuged for $5 \mathrm{~min}$ at $14,000 \times \mathrm{g}$. Immunoprecipitations were performed by adding the anti-Akt or anti-Erk1/2 antibodies and incubated overnight at $4^{\circ} \mathrm{C}$ with constant rotation. Protein G-Sepharose beads, $30 \mu \mathrm{l}$ of $50 \%$ slurry (Amersham Pharmacia Biotech, Piscataway, $\mathrm{NJ}$ ), were added and incubated under the same conditions for an additional $4 \mathrm{hr}$. Immunocomplexes were centrifuged for $2 \mathrm{~min}$ at $14,000 \times \mathrm{g}$, were washed twice in lysis buffer and twice in kinase buffer [containing (in mM) 25 Tris- $\mathrm{HCl}, \mathrm{pH} 7.5,5 \beta$-glycerol phosphate, 0.1 sodium orthovanadate, 2 dithiothreitol, and 10 magnesium chloride], and were matched for protein content before being used in each specific kinase reaction. Kinase activity assay was performed as described ( $\mathrm{Li}$ et al., 1999).

Immunoblotting. Neural progenitor cell extracts were prepared by lysing the cells on ice with lysis buffer containing protease and phosphatase inhibitor as previously described (Li et al., 1999). After SDS-PAGE the proteins were transferred to polyvinylidene difluoride membranes. The blots were developed with the enhanced chemiluminescence (ECL) kit from Amersham (Chicago, IL).

Immunofluorescence. Neural progenitor cells or sections were fixed in 4\% paraformaldehyde in PBS for $30 \mathrm{~min}$, washed in several changes of PBS for $30 \mathrm{~min}$, and permeabilized in $0.2 \%$ Triton X-100 in PBS for 15 min. Monoclonal anti-phospho-independent neurofilament-M antibody (1:200, NN18; Boehringer Mannheim), monoclonal antibody TuJ1 (Lee et al., 1990), BrdU (1:100; Becton Dickinson), or nestin (Rat 401, 1:50; Developmental Studies Hybridoma Bank, IA) incubation was performed overnight at $4^{\circ} \mathrm{C}$. After a wash in PBS (three times, 15 min each) the cells or sections were incubated with fluorescein isothiocyanate (FITC)conjugated goat anti-mouse IgG and rhodamine-labeled goat anti-rabbit $\mathrm{IgG}$ or rhodamine-labeled goat anti-mouse IgG secondary antibody for 1 $\mathrm{hr}$ at room temperature. Fluorescent images were obtained with a Zeiss LSM-410 laser-scanning confocal microscope. Colocalization studies were done of fluorescein-labeled BrdU (1:100) or nestin (1:10) and mAChR m2 (1:100 dilution; Alomone Labs, Jerusalem, Israel) or phospho-Akt (T308; 1:200; New England Biolabs, Beverly, MA). Images were processed and merged via Adobe Photoshop software.

$\left[\mathrm{Ca}^{2+}\right]_{i}$ measurements. The cytoplasm free $\mathrm{Ca}^{2+}$ concentration $\left[\mathrm{Ca}^{2+}\right]_{\mathrm{i}}$ of nestin and $\mathrm{BrdU} \mathrm{U}^{+}$progenitor cells was measured after $3 \mathrm{~d}$ of culture as previously described (Ma et al., 1998). Briefly, the cells were loaded with $1 \mu \mathrm{M}$ fluo-3 AM at room temperature for $30 \mathrm{~min}$ in physiological medium containing (in mM): $145 \mathrm{NaCl}, 5 \mathrm{KCl}, 0.8 \mathrm{MgCl}_{2}, 1.8$ $\mathrm{CaCl}_{2}, 10 \mathrm{HEPES}$, and 10 glucose, $\mathrm{pH} 7.4$, supplemented with $1 \mathrm{mg} / \mathrm{ml}$ BSA. Changes in $\left[\mathrm{Ca}^{2+}\right]_{\mathrm{i}}$ were recorded with the Zeiss Attofluor Ratio Vision workstation (Atto Instruments, Rockville, MD). Intracellular fluo-3 was excited by a $100 \mathrm{~W}$ quartz lamp filtered at $488 \mathrm{~nm}$, using a 10 $\mathrm{nm}$ bandpass filter into the excitation light path every $500 \mathrm{msec}$; proper emission wavelengths were monitored with a $520 \mathrm{~nm}$ long-pass filter, which was inserted in front of one of the ICDD cameras.

Data analysis. Data are expressed as the means \pm SEM. One-way ANOVA, followed by the Newman-Keuls test, was used as indicated in

\section{$\leftarrow$}

stained with $\mathrm{m} 2$ and BrdU antibodies. $C, \mathrm{mAChR}$ agonists induce an increase in $\left[\mathrm{Ca}^{2+}\right]_{\mathrm{i}}$ in neural progenitor cells. ACh $(50 \mu \mathrm{M})$ triggers a $\left[\mathrm{Ca}^{2+}\right]_{\mathrm{i}}$ transient increase, which was blocked by the muscarinic antagonist atropine $(50 \mu \mathrm{M})$. Muscarine $(50 \mu \mathrm{M})$ caused an even larger increase in $\left[\mathrm{Ca}^{2+}\right]_{\mathrm{i}}$ levels, indicating the presence of mAChRs in neural progenitor cells. 
the figures to determine the statistical significance; $p<0.05$ was considered significant.

\section{RESULTS}

\section{bFGF maintains rapidly dividing neural progenitor cells expressing nestin}

Cells isolated from E13 rat telencephalic neuroepithelium were expanded by the daily addition of bFGF in serum-free medium. A continuous supply of bFGF was important to repress differentiation and to maintain a homogeneous population of rapidly dividing cells expressing nestin, an intermediate filament protein characteristic of CNS precursor cells (Fig. $1 A$ ). Of the cells, $<2 \%$ expressed neuronal antigens, the astroglial marker glial fibrillary acidic protein (GFAP), or the oligodendroglial marker O4 (data not shown). Withdrawal of bFGF initiated differentiation, characterized by a progressive increase in the number of cells expressing several well established neuron-specific antigens and glia markers, including $\beta$-tubulin type III (TuJ1; Fig. 1C), neurofilament-M (NF-M), and GFAP (Ma et al., 1998). It is of interest that withdrawing bFGF initiated the cellular expression of TuJ1 within $36 \mathrm{hr}$, whereas NF-M expression was delayed for $3 \mathrm{~d}$ under the same conditions (Fig. 1B). GFAP expression was not seen until day 7 after withdrawal of the bFGF (Ma et al., 1998). These experiments confirm previously established observations that bFGF-expanded neural progenitor cells could divide and, after withdrawal of bFGF, could initiate differentiation of neurons and glia (Ma et al., 1998). Thus, proliferating progenitor cells are providing an in vitro cellular model to help define intracellular signal transduction pathways that regulate neural progenitor cell proliferation and differentiation.

\section{Cortical progenitor cells express muscarinic receptor subtypes}

We determined the expression of five subtype mRNAs by using an RT-PCR technique in bFGF-expanded neural progenitor cells and found that $\mathrm{m} 2, \mathrm{~m} 3$, and $\mathrm{m} 4 \mathrm{mAChR}$ mRNAs were expressed in neural progenitor cells, whereas the $\mathrm{m} 1$ and $\mathrm{m} 5$ were not (Fig. $2 A$ ). To confirm whether $\mathrm{mAChR}$ proteins were expressed in dividing neural progenitor cells, we examined $\mathrm{m} 2$ subcellular localization by immunofluorescence analysis. We found that $\mathrm{m} 2$ protein was localized almost within the membrane in the $\mathrm{BrdU}^{+}$ cells (Fig. $2 B$ ). Because increased intracellular $\mathrm{Ca}^{2+}$ is a critical signal in determining muscarinic receptor function activity, we loaded precursor cells with $1 \mu \mathrm{M}$ fluo-3 and monitored the changes in acetylcholine and muscarine-induced $\left[\mathrm{Ca}^{2+}\right]$ increases as changes in relative fluorescence. The transient $\left[\mathrm{Ca}^{2+}\right]$ elevation induced by acetylcholine was blocked by the muscarinic receptor antagonist atropine (Fig. 2C). Subsequently, it was shown that the recorded cells were $\mathrm{BrdU}^{+}$. This analysis of $\left[\mathrm{Ca}^{2+}\right]$ responses to $\mathrm{mAChRs}$ agonists further indicates the presence of functional mAChRs in neural progenitor cells.

\section{Muscarinic receptor agonist-induced increase in DNA synthesis in the cortical progenitor cells}

Because proliferative signaling mediated by GPCRs has been implicated in embryogenesis and growth stimulation (Olashaw and Pledger, 1988; Nagata et al., 1996), we investigated whether the stimulation of muscarinic receptors might affect the proliferation of neural progenitor cells. We used $\left[{ }^{3} \mathrm{H}\right]$ thymidine incorporation into bFGF-expanded progenitor cells to evaluate DNA synthesis as a measure of cell proliferation in vitro. Carbachol (CCh), the mAChR agonist, significantly increased DNA synthesis indicated by $\left[{ }^{3} \mathrm{H}\right]$ thymidine incorporation, and this effect was
A
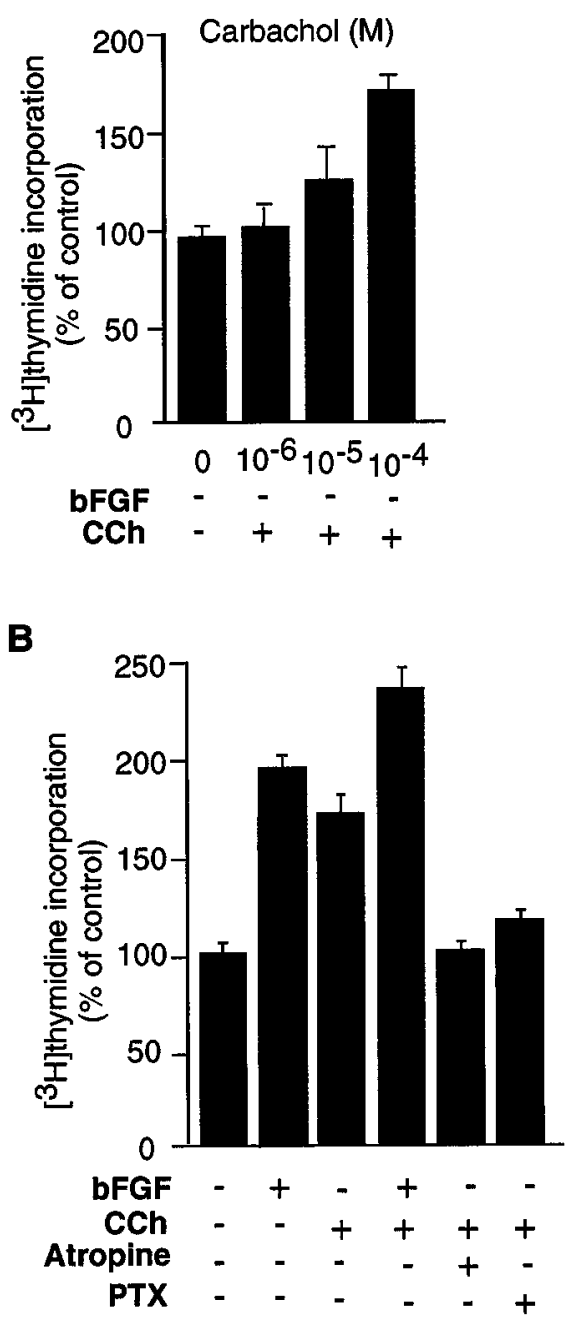

Figure 3. Effect of carbachol on the incorporation of $\left[{ }^{3} \mathrm{H}\right]$ thymidine in cultures of neural progenitor cells. Cortical progenitor cells were bFGFexpanded for $3 \mathrm{~d}$. Before the addition of $\mathrm{mAChR}$ agonists and antagonists, bFGF was removed for $24 \mathrm{hr}$, and the cells were subjected to stimulation with carbachol $(100 \mu \mathrm{M})$, carbachol plus atropine $(50 \mu \mathrm{M})$, or PTX $(100 \mathrm{ng} / \mathrm{ml})$. [ ${ }^{3} \mathrm{H}$ ] thymidine $(2.5 \mu \mathrm{Ci} / \mathrm{ml})$ was added during the last $6 \mathrm{hr}$ of culture. $A$, Dose-dependent analysis of carbachol stimulation of proliferation in neural progenitor cells. Cells were treated with different concentrations of carbachol; $\left[{ }^{3} \mathrm{H}\right]$ thymidine incorporation was measured as an index of DNA synthesis. Results are the means \pm SEM of four independent experiments. $B$, Effects of carbachol and carbachol plus atropine or PTX on $\left[{ }^{3} \mathrm{H}\right]$ thymidine incorporation in neural progenitor cells. Results are the means \pm SEM of four independent experiments.

blocked by atropine, a selective muscarinic antagonist and PTX (Fig. $3 B$ ). We also showed that $\mathrm{CCh}$ produced a dose-dependent increase in $\left[{ }^{3} \mathrm{H}\right]$ thymidine incorporation, with $100 \mu \mathrm{M}$ carbachol stimulating DNA synthesis the most (Fig. $3 A$ ).

Role of $\mathrm{mAChRs}$ on progenitor cell proliferation in vivo Recently, there have been numerous studies to investigate the role of trophic factors, e.g., epidermal growth factor (EGF) and basic fibroblast growth factor (bFGF), on neural progenitor cell proliferation in vitro (Ray and Gage, 1994; Santa-Olalla and Covarrubias, 1999) and in vivo (Kuhn et al., 1997; Gritti et al., 1999); however, there has been no information about the role of mAChRs on neural progenitor cell proliferation in vivo. To in- 

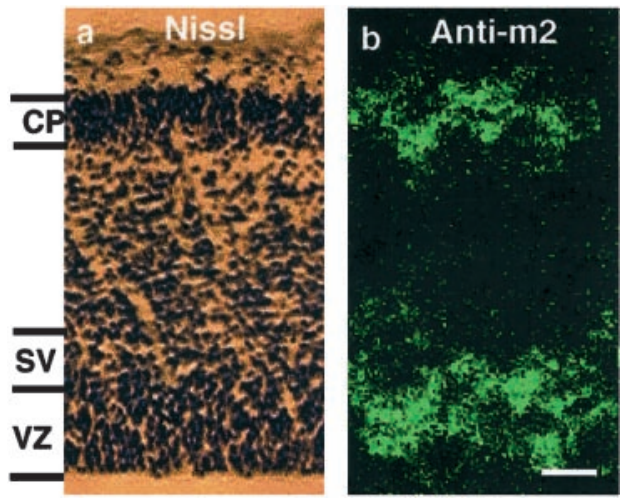

Figure 4. Muscarnic acetylcholine receptor expressed in the ventricular $(v z)$ and subventricular $(s v)$ zones of the embryonic cortex. Nissl staining $(a)$ and immunofluorescence that uses an anti-m2 antibody $(b)$ show a widespread distribution of $\mathrm{m} 2 \mathrm{AChR}$-immunoreactive cells in the $\mathrm{vz}$ and sv zones and cortical plate $(C P)$ of coronal sections of E17 rat cortex. Scale bar, $150 \mu \mathrm{m}$.

vestigate that mAChRs may play roles in the proliferation of neural progenitor cells in vivo, we first determined whether mAChRs are expressed in progenitors during the appropriate times during development. We showed that the prominent $\mathrm{m} 2$ AChR-immunoreactive cells were detected in the ventricular (VZ) and subventricular (SV) zones of the cerebral cortex of E17 embryos (Fig. 4). Because the most proliferating neuroepithelial cells are in the VZ zone (Bayer and Altman, 1991), the indication is that proliferating cells express $\mathrm{m} 2 \mathrm{AChR}$. We next demonstrated the effects of carbachol and carbachol plus atropine administration on proliferating cells in the ventricular and subventricular zones. We found that carbachol increased BrdU incorporation in the VZ and SV zones (Fig. 5). This effect was inhibited by the administration of atropine (Fig. 5), supporting proliferative roles for mAChRs in stem or progenitor cells in vivo.

\section{DNA synthesis mediated by muscarinic receptors via activation of MAP kinase pathway in the cortical progenitor cells}

The question arises as to how the signals at muscarinic receptors are translated into the stimulation of DNA synthesis and cell proliferation. Several signal transduction pathways downstream from G-protein-coupled receptors have been implicated in different cell systems (Olashaw and Pledger, 1988; Nagata et al., 1996). Among these are the mitogen-activated protein kinase (MAPK) or extracellular-regulated kinases (Erk1/2) cascade and PI-3K pathways (Crespo et al., 1994; Larocca and Almazan, 1997; Lopez-Ilasaca et al., 1997). The latter, by virtue of its effect on the phosphorylation of phosphoinositides, seems to be involved in many aspects of cell behavior from cell adhesion to cell survival (Toker and Cantley, 1997). To determine whether Erk1 and Erk2 are involved in the downstream pathway from CCh-stimulated muscarinic receptors, we investigated CCh-induced DNA synthesis, Erk1/2 phosphorylation, and kinase activity in the neural progenitor cells. We found that $100 \mu \mathrm{M} \mathrm{CCh}$ significantly increased Erk1/2 phosphorylation, kinase activity (Fig. 6A,B), and $\left[{ }^{3} \mathrm{H}\right]$ thymidine (Fig. $6 C$ ) or BrdU (data not shown) incorporation into neural progenitor cells. These effects were reduced significantly in the presence of PD98059 $(25 \mu \mathrm{M})$, a MEK-selective inhibitor (Fig. 6), implying that the G-protein-coupled muscarinic receptor appears to regulate neural progenitor cell proliferation via the $\mathrm{MEK}-$ Erk1/2 signaling pathway.
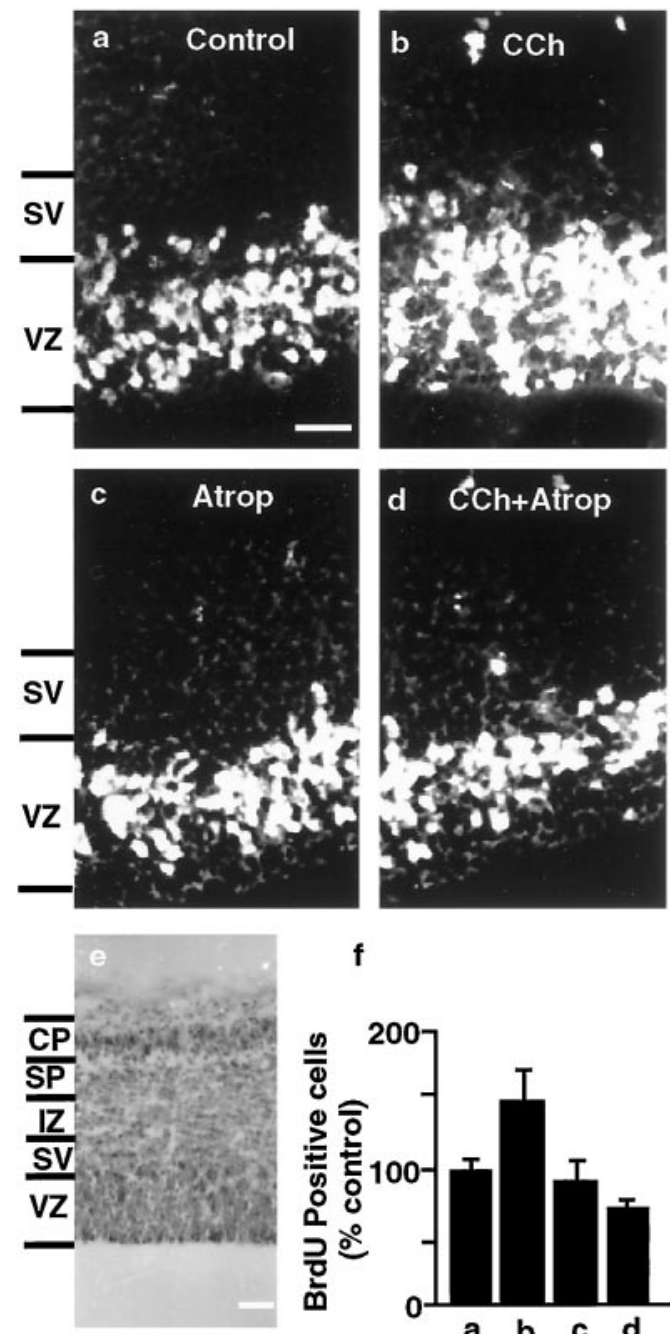

$\mathbf{f}$

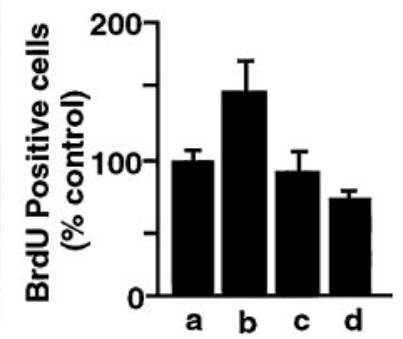

Figure 5. Effect of carbachol administration on proliferating cells in the ventricular and subventricular zones. Pregnant female rats at E16.5 of gestation were injected intraperitoneally with BrdU $(100 \mathrm{mg} / \mathrm{gm}$ of body weight), and cortices from pups were used for BrdU staining $8 \mathrm{hr}$ after injection, as described in Materials and Methods. $e$, A light micrograph of coronal-sectioned rat brain at E17 stained with Nissl showing normal lamination of the cerebral cortical wall consisting of cortical plate $(C P)$, cortical subplate $(S P)$, intermediate zone $(I Z)$, subventricular zone $(S V)$, and ventricular zone $(V Z)$. Scale bar, $150 \mu \mathrm{m}$. Strong BrdU ${ }^{+}$cells can be seen with the administration of carbachol sections throughout all ventricular and some subventricular zones $(b)$ as compared with control sections (a). These effects can be reduced by the administration of atropine alone $(c)$ or with atropine and carbachol $(d) . f$, Quantitative analysis of BrdU ${ }^{+}$ cells after the administration of $\mathrm{CCh}$ and atropine. Values were expressed in a percentage of control as the means \pm SEM of three independent experiments.

\section{PI-3 kinase pathway is involved in carbachol-induced increases in DNA synthesis in the cortical progenitor cells}

Akt was identified as one of the directed targets of PI-3 kinase activation (Dudek et al., 1997; Franke et al., 1997). To assess CCh-induced PI-3 kinase activity, we investigated the ability of the Akt phosphorylation and kinase activation affecting DNA synthesis in the neural progenitor cells. CCh increased Akt phosphorylation. This is demonstrated in Figure $7 A$, using the antibody specific to phospho-Akt $\left(\mathrm{Thr}^{308}\right)$ or Ser ${ }^{473}$. Wortmannin (50 $\mathrm{nM}$ ), a PI-3 kinase-selective inhibitor, and atropine, an $\mathrm{mAChR}$ 
A

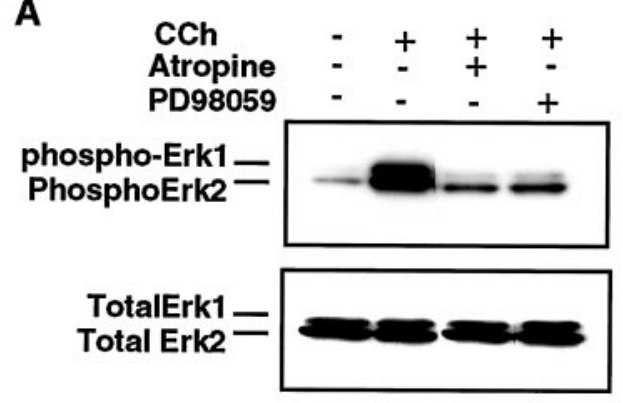

B
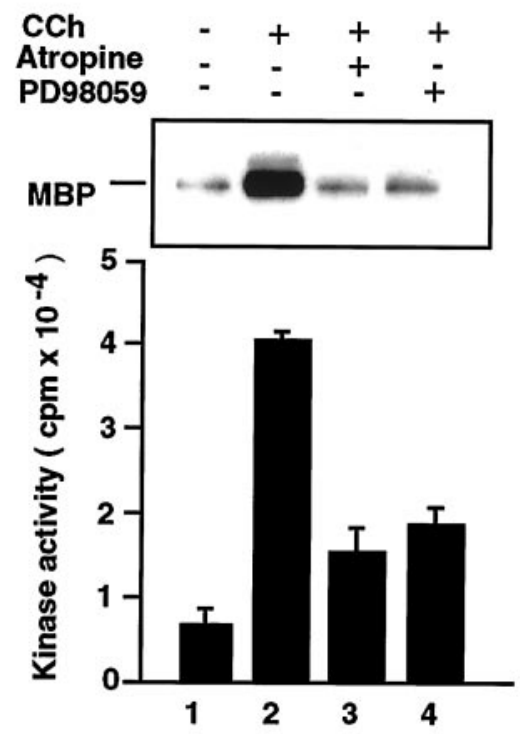

C

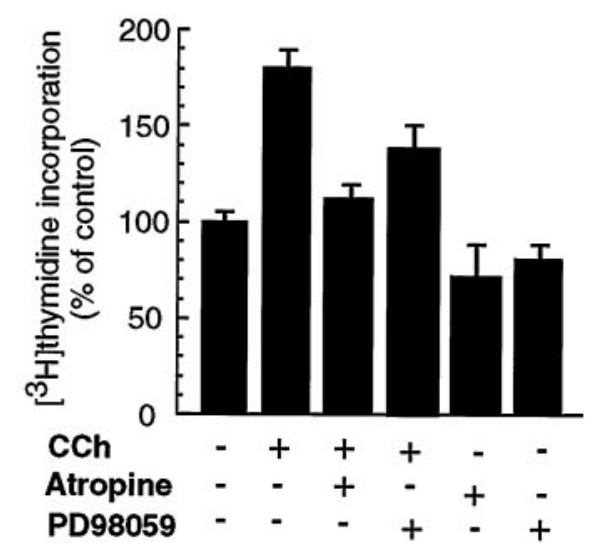

Figure 6. Erk1 and Erk2 regulate the proliferation of neural progenitor cells mediated by muscarinic receptor. $A$, Effect of atropine and PD98059 on carbachol-induced Erk1/2 phosphorylation in bFGF-deprived neural precursor cells. Cortical progenitor cells were bFGF-expanded for $3 \mathrm{~d}$; then bFGF was removed for $24 \mathrm{hr}$, and the cells were treated with atropine $(50 \mu \mathrm{M})$ or PD98059 $(25 \mu \mathrm{M})$ for $1 \mathrm{hr}$, followed by carbachol (100 $\mu \mathrm{M})$ for $30 \mathrm{~min}$. Total Erk1/2 protein and phosphorylated protein were analyzed by Western blot with anti-Erk1/2 and anti-phospho-dependent Erk1/2 antibodies. B, Effect of atropine and PD98059 on carbacholinduced Erk1/2 kinase activity in bFGF-deprived neural progenitor cells. Cortical precursor cells were bFGF-expanded for $3 \mathrm{~d}$; then bFGF was removed for $24 \mathrm{hr}$, and the cells were treated with atropine $(50 \mu \mathrm{M})$ or PD98059 $(25 \mu \mathrm{M})$ for $1 \mathrm{hr}$, followed by carbachol $(100 \mu \mathrm{M})$ for $30 \mathrm{~min}$. Immunoprecipitates of Erk1/2 with Erk1/2 antibody were used in a kinase assay in the presence of myelin basic protein $(M B P)$ and $\left[\gamma^{32} \mathrm{P}\right] \mathrm{ATP}$. Phosphorylated MBP was separated on an $8-16 \%$ SDS polyacrylamide gel. The graph represents the means \pm SEM of three independent experiments. A representative autoradiograph is shown in Figure $4 b . C$, Effect of atropine and PD98059 on carbachol-induced DNA synthesis. Cortical progenitor cells were bFGF-expanded for $3 \mathrm{~d}$. After bFGF was antagonist, significantly inhibited CCh-induced Akt phosphorylation (Fig. 7A). The CCh-induced Akt phosphorylation was confirmed by immunofluorescence analysis that used the same phospho-dependent Akt antibody (Fig. 7B). Nestin-expressing cells in the presence of $\mathrm{CCh}$ showed a significant increase in phospho-Akt expression, which was decreased significantly in the presence of wortmannin and atropine (Fig. 7B). We next examined whether the CCh-induced increase in Akt phospho-kinase was accompanied by increased Akt kinase activity; we measured kinase activity in Akt immunoprecipitates of CCh-stimulated cortical progenitor cells pretreated with wortmannin and atropine, using histone $2 \mathrm{~B}$ as a substrate. We found that $\mathrm{CCh}$ induced Akt activity, and this effect was inhibited by wortmannin and atropine (Fig. 7C). Finally, we determine whether $\mathrm{CCh}$-induced PI-3 kinase activity could result in an increase in DNA synthesis. Neural progenitor cells were treated with carbachol only, with PI-3 kinase inhibitor, or with atropine in the presence of carbachol. BrdU and $\left[{ }^{3} \mathrm{H}\right]$ thymidine incorporation into DNA was assessed. Carbachol significantly increased $\left[{ }^{3} \mathrm{H}\right]$ thymidine (Fig. $7 D$ ) and BrdU incorporation (data not shown) as compared with control. The carbachol-stimulated $\left[{ }^{3} \mathrm{H}\right]$ thymidine incorporation into DNA was inhibited partially by the inhibitors of PI-3 kinase, wortmannin and LY294002 (Fig. 7D).

\section{Carbachol stimulation of DNA synthesis via both MAP kinase and PI-3 kinase pathways in the cortical progenitor cells}

It has been reported that the activation of MAPK (Erk1/2) by carbachol was inhibited by the PI-3 kinase inhibitor wortmannin in transfected COS-7 cells, suggesting a crosstalk between these kinase systems in these cells (Lopez-Ilasaca et al., 1997). Therefore, we investigated whether CCh-induced activation of MAP kinase affects the stimulation of PI-3 kinase. The neural progenitor cells were treated with PD98059 $(25 \mu \mathrm{M})$ or wortmannin $(50$ $\mathrm{nM})$ or LY294002 $(10 \mu \mathrm{M})$ alone or together in the presence of carbachol; the increased phosphorylation of Erk1/2 and Akt was examined by Western blot analysis. We found that the PI-3 kinase inhibitor LY294002 or wortmannin (data not shown) did not affect the activation of Erk1/2 (Fig. 8A), and the MEK inhibitor PD98059 did not affect the CCh-induced Akt activation (Fig. $8 B$ ). On the other hand, a CCh-induced increase in DNA synthesis was inhibited completely in the presence of both PD98059 $(25 \mu \mathrm{M})$ and wortmannin (50 nM) or PD98059 and LY294002 (10 $\mu \mathrm{M}$; Fig. $8 C$ ). Wortmannin or PD98059 each produced an almost $50 \%$ reduction in $\left[{ }^{3} \mathrm{H}\right]$ thymidine incorporation into DNA (Figs. $6 C, 7 D)$. These data suggest that G-protein-coupled muscarinic receptors appear to regulate DNA synthesis in neural progenitor cells via both MAP kinases and PI-3 kinase pathways.

\section{Carbachol stimulation of DNA synthesis and survival of} neural progenitor cells

Because the PI-3K and MEK-Erk1/2 pathways are thought to promote cell survival (Datta et al., 1997; Toker and Cantley, 1997; Brunet et al., 1999), it is possible that CCh stimulation of thymidine incorporation (Fig. 3) reflected a greater survival of neural progenitor cells rather than a stimulation of DNA synthe-

$$
\leftarrow
$$

removed for $24 \mathrm{hr}$, carbachol $(100 \mu \mathrm{M})$, carbachol plus atropine $(50 \mu \mathrm{M})$, or PD98059 $(25 \mu \mathrm{M})$ was added. $\left[{ }^{3} \mathrm{H}\right]$ thymidine $(2.5 \mu \mathrm{Ci} / \mathrm{ml})$ was added during the last $4 \mathrm{hr}$ of culture. $\left[{ }^{3} \mathrm{H}\right]$ thymidine incorporation was measured as an index of DNA synthesis. Results are the means \pm SEM of four independent experiments. 


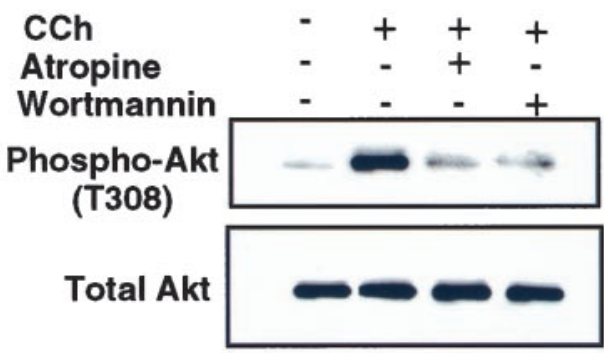

B

Anti-nestin
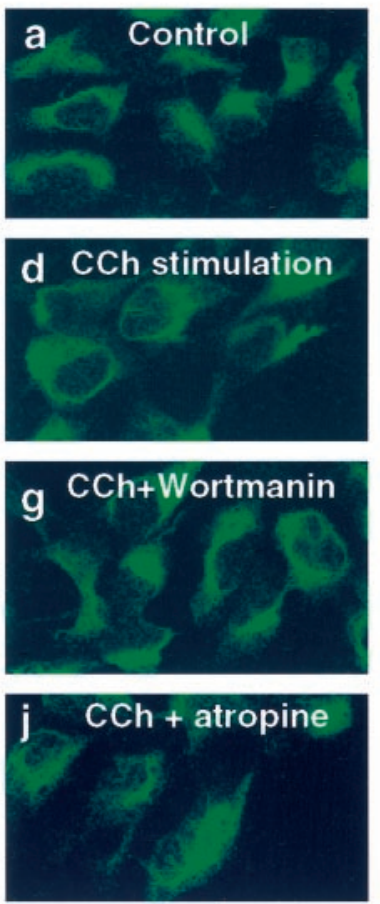

Anti-phospho-akt
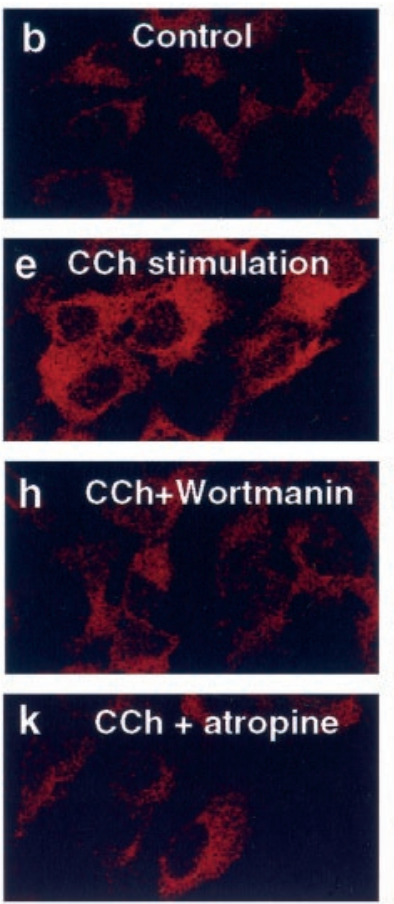

D
C

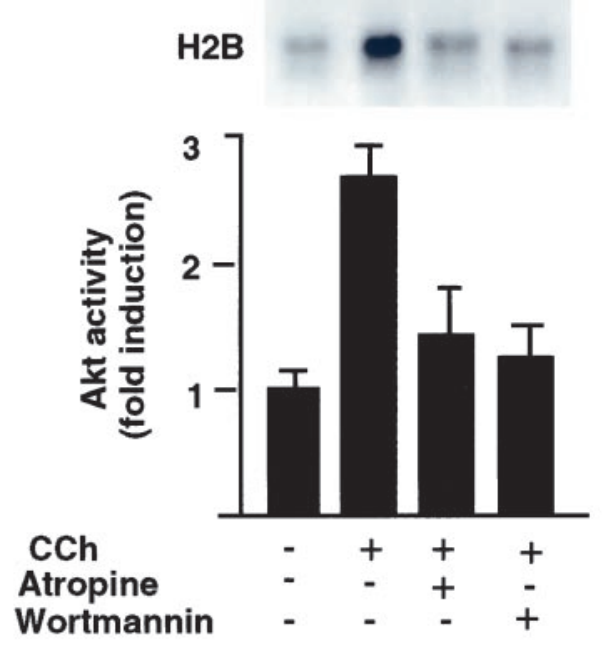

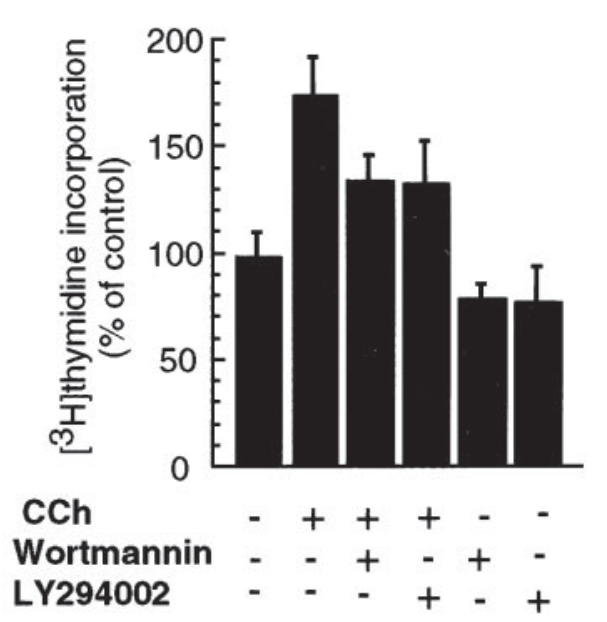

Figure 7. Carbachol activates Akt in neural progenitor cells mediated by muscarinic receptor in a wortmannin-sensitive manner. $A$, Carbachol induced Akt phosphorylation in a wortmannin-sensitive manner. Cortical progenitor cells were bFGF-expanded for $3 \mathrm{~d}$. After bFGF was removed for $24 \mathrm{hr}$, carbachol $(100 \mu \mathrm{M})$, carbachol plus wortmannin (50 nM), or carbachol plus atropine $(50 \mu \mathrm{M})$ was added for $30 \mathrm{~min}$. Cell lysates were analyzed by immunoblotting with phospho-dependent T308 and phospho-independent Akt antibodies. Blots were visualized by enhanced chemiluminescence. B, Analysis of CCh-induced Akt phosphorylation in neural progenitor cells by immunofluorescence that used a phosphodependent Akt T308 antibody. Cells were fixed and double-stained with nestin and phosphoAkt T308 antibodies, followed by a secondary layer of fluorescein-conjugated goat antibody to mouse $\mathrm{IgG}$ and Texas Red-conjugated goat antibody to rabbit IgG. Photographs are representative confocal microscopic images depicting the cellular distribution of nestin (left column) and Akt T308-phosphorylated Akt (center column). Overlay images (right column) depict the colocalization of phospho-Akt and nestin in nestin-positive neural precursor cells. $C$, Effect of wortmannin (50 nM) and atropine $(50 \mu \mathrm{M})$ on carbachol-induced Akt kinase activity in neural progenitor cells. The cells were treated as described in $A$. Cell lysate $(50 \mu \mathrm{g})$ was immunoprecipitated with an anti-Akt antibody. Immunoprecipitates were used in an immunocomplex kinase assay in the presence of histone B2 $(H 2 B)$ and $\left[\gamma^{32} \mathrm{P}\right]$ ATP. Phosphorylated H2B was separated on an $8-16 \%$ SDS polyacrylamide gel. The graph represents the means \pm SEM of three independent experiments. A representative autoradiograph is shown in Figure 5C. D, Effect of atropine and wortmannin on carbachol-induced DNA synthesis. Cortical progenitor cells were bFGFexpanded for $3 \mathrm{~d}$. After bFGF was removed for $24 \mathrm{hr}$, carbachol $(100 \mu \mathrm{M})$, carbachol plus atropine $\left(\begin{array}{ll}50 & \mu \mathrm{M}\end{array}\right)$, wortmannin $(50 \mathrm{nM})$, or LY294002 $(10 \mu \mathrm{M})$ was added. $\left[{ }^{3} \mathrm{H}\right]$ thymidine $(2.5 \mu \mathrm{Ci} / \mathrm{ml})$ was added during the last $4 \mathrm{hr}$ of culture. $\left[{ }^{3} \mathrm{H}\right]$ thymidine incorporation was measured as an index of DNA synthesis. Results are the means \pm SEM of four independent experiments. sis. To examine this possibility, we compared cell death in $\mathrm{CCh}$ alone, and in treatment with PD98059 or wortmannin (inhibitors of MEK and PI-3K) alone and in the presence of carbachol by using a TUNEL-staining apoptotic assay procedure. Under an identical experimental paradigm of bFGF treatment, carbachol stimulation, and treatment with inhibitors (see Materials and Methods) we found that $<12 \%$ of control, carbachol stimulation, and carbachol with PD98059 or wortmannin-treated cortical progenitor cell cultures displayed an apoptotic phenotype and were labeled by the TUNEL reaction $2 \mathrm{~d}$ after withdrawal of bFGF 
A

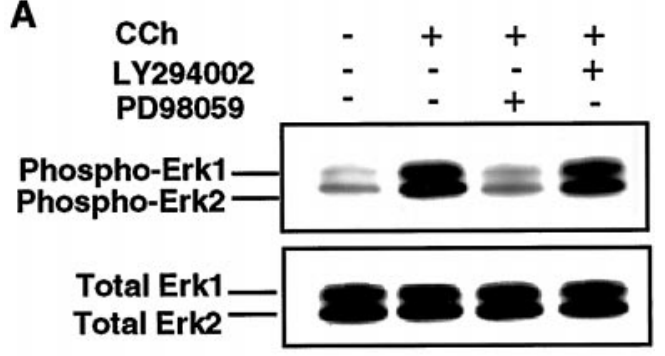

B

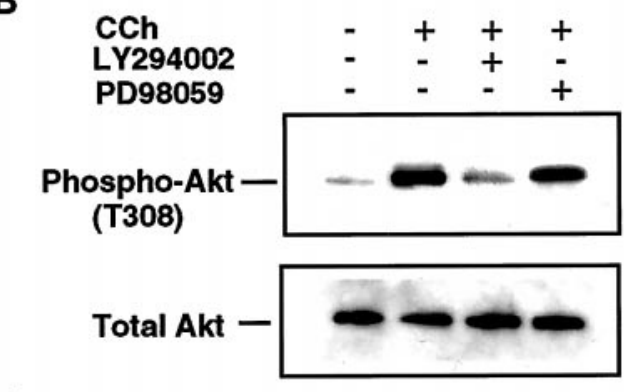

C

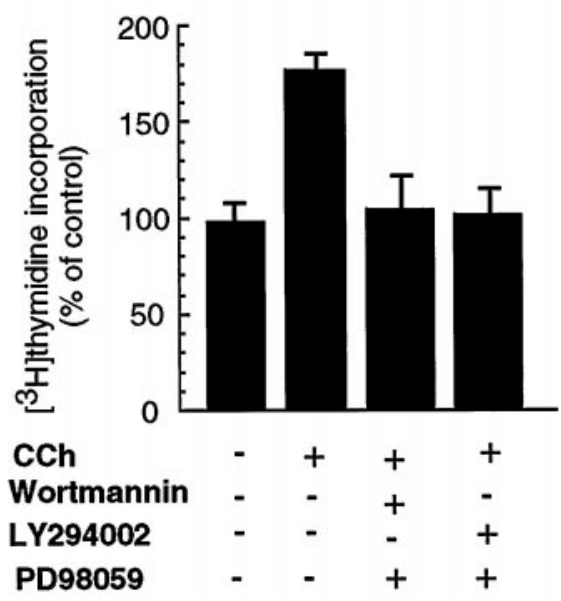

Figure 8. Carbachol stimulation of DNA synthesis in neural progenitor cells via both MAP kinase and PI-3 kinase pathways. $A$, Effect of LY294002 and PD98059 on carbachol-induced Erk1/2 phosphorylation in bFGF-deprived neural precursor cells. Cortical progenitor cells were treated as described above. Phosphorylated Erk1/2 and total Erk1/2 protein were analyzed by Western blot with anti-phospho-dependent Erk1/2 and anti-Erk1/2 antibodies. B, Effect of LY294002 and PD98059 on carbachol-induced Akt kinase activity in bFGF-deprived neural precursor cells. Cell lysates were analyzed by immunoblotting with phosphodependent T308 and Akt antibodies. C, Effect of wortmannin, LY294002, and PD98059 on carbachol-induced DNA synthesis. Cortical progenitor cells were bFGF-expanded for $3 \mathrm{~d}$. After bFGF was removed for $24 \mathrm{hr}$, carbachol $(100 \mu \mathrm{M})$ or carbachol plus wortmannin $(50 \mathrm{nM})$ and PD98059 $(25 \mu \mathrm{M})$ or LY294002 $(10 \mu \mathrm{M})$ and PD98059 $(25 \mu \mathrm{M})$ were added. $\left[{ }^{3} \mathrm{H}\right.$ thymidine $(2.5 \mu \mathrm{Ci} / \mathrm{ml})$ was added during the last $4 \mathrm{hr}$ of culture. $\left[{ }^{3} \mathrm{H}\right]$ thymidine incorporation was measured as an index of DNA synthesis. Results are the means \pm SEM of four independent experiments.

(Fig. 9A,B). At longer periods there was a significant increase of apoptotic cells. In addition, we also found that carbachol caused a decreased rate of cell death (Fig. $9 B$ ) and displayed a delay of differentiation (Fig. 9C) as compared with the control cells $2 \mathrm{~d}$ after withdrawal of bFGF. These results suggest that the extent of cell death in treated and control cultures is similar after the withdrawal of bFGF for $2 \mathrm{~d}$ and that the greater levels of thymidine incorporation in CCh-treated cultures were correlated with
CCh-induced Erk1/2 and PI-3 kinase activity to stimulate DNA synthesis and to maintain survival in the cortical progenitor cells.

\section{DISCUSSION}

During CNS development it is essential that appropriate numbers of neurons and glia are produced to establish normal brain functions. It is well established that the regulation of both progenitor cell proliferation and neuronal cell death depends on an interaction of diverse extracellular signal molecules linked to a network of intracellular signal transduction pathways. Elucidating the regulatory mechanisms that control neural progenitor cell proliferation is important for understanding how intracellular signal transduction pathways regulate proliferation during early neurogenesis. In the present study we show that the acetylcholine agonist carbachol, acting via mAChR, activates MAPK and PI-3 kinase, resulting in increases in DNA synthesis in the neural precursor cells. These data suggest that acetylcholine acting via $\mathrm{mAChR}$ functions as a mitogen that activates MAPK and PI-3K and is involved in DNA synthesis during early neurogenesis.

Accumulating evidence indicates that GPCRs and their signaling molecules are important for growth stimulation (Rozengurt, 1986; Gutkind, 1998). Many ligands acting via GPCRs elicit a mitogenic response in a variety of cell types (Rozengurt, 1986; Pages et al., 1993); recent studies suggest that certain GPCRs are essential for cell growth under physiological conditions (Burstein et al., 1998). Although the mechanism or mechanisms whereby GPCRs regulate cell proliferation remain poorly understood, several lines of investigation have implicated the family of extracellular signal-regulated kinases (Erk1 and Erk2) or MAP kinases as a critical component of mitogenesis in promoting cell growth (Davis, 1993; Schlessinger, 1993). Consistent with the proposed role of MAPKs and the results of our experiments showing Erk1/2 activation inducing increases in $\left[{ }^{3} \mathrm{H}\right]$ thymidine uptake as a result of $\mathrm{CCh}$ stimulation in neural progenitor cells, we propose signaling from $\mathrm{mAChR}$ to Ras, thereby initiating a cascade of events leading to MAP kinase kinase such as MEK1 and MEK2 activation. MEKs ultimately phosphorylate Erk1 and Erk 2 on both threonine and tyrosine residues. In turn, Erk1/2 phosphorylate and regulate the expression of genes, such as transcription factors, which are essential for neural progenitor cell proliferation.

The results of the experiment (Fig. 6) showed that PD98059 significantly reduced carbachol-induced Erk1/2 activation and DNA synthesis; however, PD98059 only partially inhibited CChinduced DNA synthesis, thus suggesting that an alternate mechanism to the MEK-Erk1/2 pathway is involved in regulating DNA synthesis in the neural progenitor cells. PI-3K recently was shown to play a central role in promoting the survival of a wide range of cell types (Datta et al., 1997; Brunet et al., 1999). There has also been the recent suggestion that, at least in IL-2 signaling, PI-3 kinase with its downstream target Akt may be important for cytokine-driven proliferation (Roche et al., 1994; Brennan et al., 1997). These data prompted us to explore whether the activation of PI-3 kinase by muscarinic receptors also might participate in regulating neural progenitor cell proliferation. To test this hypothesis, we investigated CCh-induced PI-3 kinase activity in neural progenitor cells. Potential links between GPCRs and the PI-3K signaling pathway also have been identified recently (Murga et al., 1998). Data presented in Figure 7 demonstrated that the $\mathrm{CCh}$-induced increased in $\left[{ }^{3} \mathrm{H}\right]$ thymidine incorporation 
A

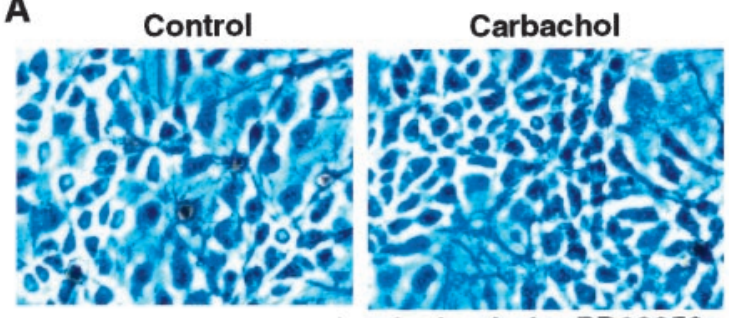

Carbachol+Wortmannin Carbachol + PD98059
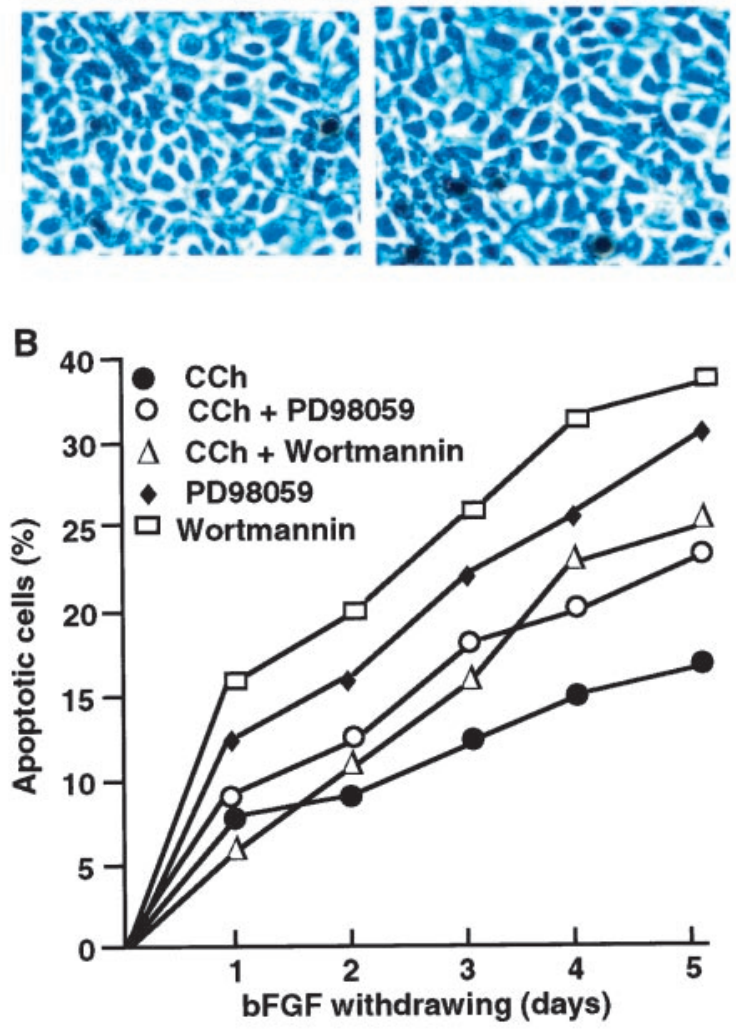

C

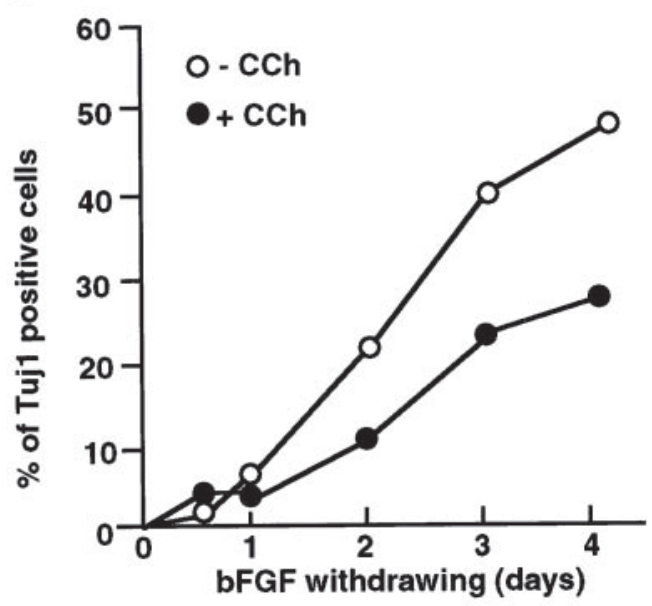

Figure 9. Carbachol stimulation and its effect on neural progenitor cell proliferation and survival. $A$, A representative field TUNEL staining of control cells and carbachol alone or cells treated with inhibitors $2 \mathrm{~d}$ after the withdrawal of bFGF. Cells were photographed in a light microscope. $B$, Neural progenitor cells were grown to an approximate density of $1 \times$ $10^{5}$ cells $/ \mathrm{cm}^{2}$ in $35 \mathrm{~mm}$ plastic dishes for $3 \mathrm{~d}$. Cultures were bFGFdeprived and treated in the presence of carbachol alone, or inhibitors were added up to $5 \mathrm{~d}$; the percentage of apoptosis was determined by counting labeled nuclei from different fields. Results from four indepen- in neural progenitor cells was inhibited almost equally by both PD98059, an MEK inhibitor, and PI-3 kinase inhibitors (wortmannin or LY294002). In the presence of both kinase (MEK and PI-3 kinase) inhibitors, the increase in $\left[{ }^{3} \mathrm{H}\right]$ thymidine incorporation produced by carbachol was inhibited completely to basal level (Fig. 8C). These results are consistent with a role for PI-3K and MAPK signaling in CCh stimulation of neural precursor cell proliferation. Recently, Lopez-Ilasaca et al. (1997) observed that a novel PI-3K isotype, termed PI-3K $\gamma$, was found to link G-protein-coupled receptors and activated MAP kinase. This suggests a potential mechanism whereby $\mathrm{mAChR}$ can regulate crosstalk between PI-3 kinase and MAP kinase. In the present study we explored this possibility by using specific inhibitors of these kinases (Fig. 8). We found that carbachol stimulated both MAPK (Erk1/2) and PI-3 kinase, but inhibition of either one did not affect the activity of other kinase.

PI-3 kinase has many targets, including Akt, PDK1, and ILK, which can regulate PKC isoforms, p70S6 kinase, GSK-3, and PKA (Monfar et al., 1995; Batty et al., 1997; Delcommenne et al., 1998; Le Good et al., 1998; Cass et al., 1999; Wu, 1999). In addition to other kinases, GSK-3 is a critical downstream element of Akt (Pap and Cooper, 1998). GSK-3 has been shown to phosphorylate several other proteins, including $\beta$-catenin and the transcription factors c-Jun, c-Myc, c-Myb, and CREB; several of these substrates are implicated in oncogenesis and cell proliferation (Plyte et al., 1992; Dickinson et al., 1994; Miller and Moon, 1996). Recently, it has been shown that GSK-3 $\beta$ catalyzes cyclin D1 phosphorylation on $\mathrm{Thr}^{286}$, thereby regulating cyclin D1 turnover. This results in a redistribution of cyclin D1 from the cell nucleus to the cytoplasm with proteosomal degradation during cell proliferation. Cyclin D1 turnover can be stabilized by overexpression of a constitutively active isoform of Akt (Diehl et al., 1998). The present data support the hypothesis that the G-protein-coupled mAChR activation of the PI-3K pathway phosphorylates GSK- $3 \beta$ and results in the inhibition of cyclin D1 phosphorylation, turnover, and redistribution. This may lead to an increase in DNA synthesis and cell proliferation.

Proliferation requires cell survival, but survival can occur without proliferation. The MEK-Erk1/2 and PI-3 kinase are thought to promote cell survival (Datta et al., 1997; Songyang et al., 1997; Toker and Cantley, 1997; Brunet et al., 1999). Therefore, it is important to measure carbachol-induced cell proliferation and survival. Our data indicate that the extent of cell death in CCh-treated cells or those cells treated together with PD98059 or wortmannin and in control cells is similar $2 \mathrm{~d}$ after the withdrawal of bFGF. Thus, we excluded the possibility that $\mathrm{CCh}$ stimulation of thymidine incorporation reflected a greater survival of neural progenitor cells rather than a stimulation of DNA synthesis (at least under these conditions), suggesting that mAChR-mediated MAP kinase and PI-3 kinase activity may play a key role in promoting neural progen-

dent experiments are shown as the means \pm SEM. Day 0 indicates the day before bFGF withdrawal (control). The numbers of apoptotic cells at day 0 were normalized as $0 \%$ for comparing the apoptotic cells under different treatment conditions. $C$, Cells were treated as described in $B$. Immunostaining for the neuronal marker Tuj1 and cell counting were performed up to $4 \mathrm{~d}$ after the withdrawal of bFGF. The percentage of Tuj1 $1^{+}$cells was counted from different fields. Results from four independent experiments are shown as the means \pm SEM. 
itor cell proliferation. These findings raise the possibility that, in addition to promoting cell survival, PI-3K and MAP kinase signal transduction pathways regulate the proliferation of neural progenitor cells during early neurogenesis.

\section{REFERENCES}

Ahmed NN, Grimes HL, Bellacosa A, Chan TO, Tsichlis PN (1997) Transduction of interleukin-2 anti-apoptotic and proliferative signals via Akt protein kinase. Proc Natl Acad Sci USA 94:3627-3632.

Ashkenazi A, Ramachandran J, Capon DJ (1989) Acetylcholine analogue stimulates DNA synthesis in brain-derived cells via specific muscarinic receptor subtypes. Nature 340:146-150.

Batty IH, Hickinson DM, Downes CP (1997) Cross-talk between phospholipase $\mathrm{C}$ and phosphoinositide-3 kinase signaling pathways. Biochem Soc Trans 25:1132-1137.

Bayer SA, Altman J (1991) Neocortical development. New York: Raven. Blokland A (1995) Acetylcholine: a neurotransmitter for learning and memory? Brain Res Brain Res Rev 21:285-300.

Brennan P, Babbage JW, Burgering BM, Groner B, Reif K, Cantrell DA (1997) Phosphatidylinositol-3 kinase couples the interleukin-2 receptor to cell cycle regulator E2F. Immunity 7:679-689.

Brunet A, Bonni A, Zigmond MJ, Lin MZ, Juo P, Hu LS, Anderson MJ, Arden KC, Blenis J, Greenberg ME (1999) Akt promotes cell survival by phosphorylating and inhibiting a forkhead transcription factor. Cell 96:857-868.

Burstein ES, Hesterberg DJ, Gutkind JS, Brann MR, Currier EA, Messier TL (1998) The ras-related GTPase rac1 regulates a proliferative pathway selectively utilized by G-protein-coupled receptors. Oncogene 17:1617-1623.

Cass LA, Summers SA, Prendergast GV, Backer JM, Birnbaum MJ, Meinkoth JL (1999) Protein kinase A-dependent and -independent signaling pathways contribute to cyclic AMP-stimulated proliferation. Mol Cell Biol 19:5882-5891.

Cohen RI, Molina-Holgado E, Almazan G (1996) Carbachol stimulates c-fos expression and proliferation in oligodendrocyte progenitors. Brain Res Mol Brain Res 43:193-201. Crespo P, Xu N, Simonds WF, Gutkind JS (1994) Ras-dependent activation of MAP kinase pathway mediated by G-protein $\beta \gamma$ subunits. Nature 369:418-420.

Crespo P, Xu N, Simonds WF, Gutkind JS (1994) Ras-dependent activation of MAP kinase pathway mediated by G-protein $\beta \gamma$ subunits. Nature 369:418-420.

Cui H, Meng Y, Bulleit RF (1998) Inhibition of glycogen synthase kinase $3 \beta$ activity regulates proliferation of cultured cerebellar granule cells. Dev Brain Res 111:177-188.

Datta SR, Dudek H, Tao X, Masters S, Fu H, Gotoh Y, Greenberg ME (1997) Akt phosphorylation of BAD couple's survival signals to the cell-intrinsic death machinery. Cell 91:231-241.

Davis RJ (1993) The mitogen-activated protein kinase signal transduction pathway. J Biol Chem 268:14553-14556.

Delcommenne M, Tan C, Gray V, Rue L, Woodgett J, Dedhar S (1998) Phosphoinositide-3-OH kinase-dependent regulation of glycogen synthase kinase-3 and protein kinase B/AKT by the integrin-linked kinase. Proc Natl Acad Sci USA 95:11211-11216.

Dickinson ME, Krumlauf R, McMahon AP (1994) Evidence for a mitogenic effect of Wnt-1 in the developing mammalian central nervous system. Development 120:1453-1471.

Diehl JA, Cheng M, Rousse MF, Sherr CJ (1998) Glycogen synthase kinase- $3 \beta$ regulates cyclin D1 proteolysis and subcellular localization. Gene Dev 12:3499-3511.

Dudek H, Datta SR, Franke TF, Birnbaum MJ, Yao R, Cooper GM, Segal RA, Kaplan DR, Greenberg ME (1997) Regulation of neuronal survival by the serine-threonine protein kinase Akt. Science 275:661-665.

Franke TF, Kaplan DR, Cantley LC, Toker A (1997) Direct regulation of the Akt proto-oncogene product by phosphatidylinositol-3,4bisphosphate. Science 275:665-668.

Fraser CM, Lee NH, Pellegrino SM, Kerlavage AR (1994) Molecular properties and regulation of G-protein-coupled receptors. Prog Nucleic Acid Res Mol Biol 49:113-156.

Gritti A, Frolichsthal-Schoeller P, Galli R, Parati EA, Cova L, Pagano SF, Bjornson CR, Vescovi AL (1999) Epidermal and fibroblast growth factors behave as mitogenic regulators for a single multipotent stem cell-like population from the subventricular region of the adult mouse forebrain. J Neurosci 19:3287-3297.

Gudermann T, Schoneberg T, Schultz G (1997) Functional and structural complexity of signal transduction via G-protein-coupled receptors. Annu Rev Neurosci 20:399-427.

Guizzetti M, Costa P, Peters J, Costa LG (1996) Acetylcholine as a mitogen: muscarinic receptor-mediated proliferation of rat astrocytes and human astrocytoma cells. Eur J Pharmacol 297:265-273.

Gutkind JS (1998) The pathways connecting G-protein-coupled receptors to the nucleus through divergent mitogen-activated protein kinase cascades. J Biol Chem 273:1839-1842.
Hadcock JR, Malbon CC (1993) Agonist regulation of gene expression of adrenergic receptors and G-proteins. J Neurochem 60:1-9.

Hayashi Y, Koike M, Matsutani M, Hoshino T (1988) Effects of fixation time and enzymatic digestion on immunohistochemical demonstration of bromodeoxyuridine in formalin-fixed, paraffin-embedded tissue. J Histochem Cytochem 36:511-514.

Hepler JR, Gilman AG (1992) G-proteins. Trends Biochem Sci 17:383-387

Hosli E, Hosli L (1993) Receptors for neurotransmitters on astrocytes in the mammalian central nervous system. Prog Neurobiol 40:477-506.

Jerusalinsky D, Kornisiuk E, Izquierdo I (1997) Cholinergic neurotransmission and synaptic plasticity concerning memory processing. Neurochem Res 22:507-515.

Jones MW, French PJ, Bliss TV, Rosenblum K (1999) Molecular mechanisms of long-term potentiation in the insular cortex in vivo. J Neurosci 19:RC361-RC368.

Kuhn HG, Winkler J, Kempermann G, Thal LJ, Gage FH (1997) Epidermal growth factor and fibroblast growth factor-2 have different effects on neural progenitors in the adult rat brain. J Neurosci 17:5820-5829.

Larocca JN, Almazan G (1997) Acetylcholine agonists stimulate mitogen-activated protein kinase in oligodendrocyte progenitors by muscarinic receptors. Neurosci Res 50:743-754.

Lauder JM (1993) Neurotransmitters as growth regulatory signals: role of receptors and second messengers. Trends Neurosci 16:233-240.

Lee MK, Tuttle JB, Rebhun LI, Cleveland DW, Frankfurter A (1990) The expression and post-translational modification of a neuron-specific $\beta$-tubulin isotype during chick embryogenesis. Cell Motil Cytoskeleton $17: 118-132$.

Le Good JA, Ziegler WH, Parekh DB, Alessi DR, Cohen P, Parker PJ (1998) Protein kinase C isotypes controlled by phosphoinositide-3 kinase through the protein kinase PDK1. Science 281:2042-2045.

Li BS, Veeranna, Gu J, Grant P, Pant HC (1999) Activation of mitogenactivated protein kinases (Erk1 and Erk2) cascade results in phosphorylation of NF-M tail domains in transfected NIH 3T3 cells. Eur J Biochem 262:211-217.

Liu J, Morrow AL, Devaud L, Grayson DR, Lauder JM (1997) GABA receptors mediate trophic effects of GABA on embryonic brainstem monoamine neurons in vitro. J Neurosci 17:2420-2428.

Lopez-Ilasaca M, Crespo P, Pellici PG, Gutkind JS, Wetzker R (1997) Linkage of G-protein-coupled receptors to the MAPK signaling pathway through PI-3 kinase- $\gamma$. Science 275:394-397.

Ma W, Liu OY, Maric D, Sathanoori R, Chang YH, Barker JL (1998) Basic FGF-responsive telencephalic precursor cells express functional $\mathrm{GABA}_{\mathrm{A}}$ receptor/Cl channels in vitro. J Neurobiol 35:277-286.

McIlroy J, Chen D, Wjasow C, Michaeli T, Backer JM (1997) Specific activation of p85-p110 phosphatidylinositol-3' kinase stimulates DNA synthesis by ras- and p70S6 kinase-dependent pathways. Mol Cell Biol $17: 248-255$.

Miller JR, Moon RT (1996) Signaling transduction through $\beta$-catenin and specification of cell fate during embryogenesis. Gene Dev 10:2527-2539.

Monfar M, Lemon KP, Grammer TC, Cheatham L, Chung J, Vlahos CJ, Blenis J (1995) Activation of pp70/85 S6 kinases in interleukin-2responsive lymphoid cells is mediated by phosphatidylinositol-3 kinase and inhibited by cyclic AMP. Mol Cell Biol 15:326-337.

Murga C, Laguinge L, Wetzker R, Guadrado A, Gutkind JS (1998) Activation of Akt/protein kinase B by G-protein-coupled receptors: a role for $\alpha$ and $\beta \gamma$ subunits of heterotrimeric G-proteins acting through phosphatidylinositol-3-OH kinase $\gamma$. J Biol Chem 273:19080-19085.

Nagata A, Ito M, Iwata N, Kuno J, Takano O, Chihara K, Matsui T, Noda $\mathrm{T}$ (1996) G-protein-coupled cholecystokinin-B/gastrin receptors are responsible for physiological cell growth of the stomach mucosa in vivo. Proc Natl Acad Sci USA 93:11825-11830.

Olashaw NE, Pledger WJ (1988) Cellular mechanisms regulating proliferation. Adv Second Messenger Phosphoprotein Res 22:139-173.

Orban PC, Chapman PF, Brambilla R (1999) Is the Ras-MAPK signaling pathway necessary for long-term memory formation? Trends Neurosci $22: 38-44$

Pages G, Lenormand P, L'Allemain G, Chambard JC, Meloches S, Pouyssegur J (1993) Mitogen-activated protein kinase $\mathrm{p} 42^{\text {mapk }}$ and p44 ${ }^{\mathrm{mapk}}$ are required for fibroblast proliferation. Proc Natl Acad Sci USA 90:8319-8323.

Pap M, Cooper GM (1998) Role of glycogen synthase kinase-3 in the phosphatidylinositol-3 kinase/Akt cell survival pathway. J Biol Chem 273:19929-19932.

Plyte SE, Hughes K, Nikolakaki K, Pulverer BJ, Woodgett JR (1992) Glycogen synthase kinase-3: functions in oncogenesis and development. Biochim Biophys Acta 1114:147-162.

Ray J, Gage FH (1994) Spinal cord neuroblasts proliferate in response to basic fibroblast growth factor. J Neurosci 14:3548-3564.

Roche S, Koegl M, Courtneidge SA (1994) The phosphatidylinositol-3 kinase $\alpha$ is required for DNA synthesis induced by some, but not all, growth factors. Proc Natl Acad Sci USA 91:9185-9189.

Rosenblum K, Futter M, Jones M, Hulme EC, Bliss TV (2000) ERKI/II 
regulation by the muscarinic acetylcholine receptors in neurons. J Neurosci 20:977-985.

Rozengurt E (1986) Early signals in the mitogenic response. Science 234:161-166.

Santa-Olalla J, Covarrubias L (1999) Basic fibroblast growth factor promotes epidermal growth factor responsiveness and survival of mesencephalic neural precursor cells. J Neurobiol 40:14-27.

Schlessinger J (1993) How receptor tyrosine kinases activate Ras. Trends Biochem Sci 18:273-275.

Songyang Z, Baltimore D, Cantley LC, Kaplan DR, Franke TF (1997) Interleukin-3-dependent survival by the Akt protein kinase. Proc Natl Acad Sci USA 94:11345-11350.

Stephan CC, Sastry BV (1992) Characterization of the subtype of mus- carinic receptor coupled to the stimulation of phosphoinositide hydrolysis in 132-1N1 human astrocytoma cells. Cell Mol Biol 38:701-712.

Toker A, Cantley LC (1997) Signaling through the lipid products of phosphoinositide-3-OH kinase. Nature 387:673-676.

Trejo J, Brown JH (1991) c-fos and c-jun are induced by muscarinic receptor activation of protein kinase $\mathrm{C}$ but are differentially regulated by intracellular calcium. J Biol Chem 266:7876-7882.

Wan Y, Kurosaki T, Huang XY (1996) Tyrosine kinases in activation of the MAP kinase cascade by G-protein-coupled receptors. Nature 380:541-544

Wu C (1999) Integrin-linked kinase and PINCH: partners in regulation of cell-extracellular matrix interaction and signal transduction. Cell Sci 112:4485-4489. 